\title{
*Induction of Genetic Variability by Colchicine Treatment in Stevia rebaudiana Bertoni.
}

Received : 7/12/2017

Accepted : 18/1/2018

\author{
Suhad A. Mahdi ${ }^{1}$, Chandra Mohan Meena ${ }^{2}$, Dr. Ashok Tholakabavi ${ }^{3}$ \\ ${ }^{1}$ Assistant teacher, Horticulture dept., Agriculture College, Uni. Of Baghdad, Iraq. \\ ${ }^{2}$ Reacher, Dept. of Plant Biotechnology, Uni. Of Agricultural science. Bangalore, India. \\ ${ }^{3}$ Professor, Dept. of Plant Biotechnology, Uni. Of Agricultural science, Bangalore, India. \\ Correspondence to:Suhad.mahdi2010@gmail.com
}

\begin{abstract}
:
In this study polyploidy was induced in Stevia rebaudiana Bertoni, $(2 \mathrm{n}=22)$ by using different concentrations of colchicine $(0.25 \%, 0.50 \%, 0.75 \%, 1.0 \%, 1.50 \%$, and $2.5 \%$ ). Morphological measurements like plant height, leaf length, width and thickness, stomata number per unit area and number of inflorescences per plant were studied. Analysis of variance revealed highly significant differences among the plants. Flow cytometry analyses, identified the ploidy level. The results showed that the percentage of Stevioside content in leaves were (two and half times) higher than the tetraploid plants compared to control.
\end{abstract}

Key words: Asteraceae, polyploidy, Stevia rebaudiana, Stevioside, flow-cytometry.

\section{Introduction:}

Stevia rebaudiana (Bertoni) is known as sweet leaf, or sugar leaf. It is a herbaceous perennial $(2 n=22)$, member of the family Asteraceae genus Stevia Cav., and its native to Paraguay. Consists of approximately 350 species of herbaceous, shrub and sub-shrub, they are entomophilous plant. Leaves of Stevia produce diterpene glycosides, which are non-nutritive, non-toxic, high-intensity sweeteners and may substitute sucrose and also other manufactured sweeteners; these alkaloids are 300 times sweeter than sucrose. These alkaloids are 300 times sweeter than sucrose. In addition to its sweetening property, it has medicinal values and uses [1]. Plants breeders were initially attracted to induce polyploidy primarily because of the gigas effects, which increased cell size (but also reduced fertility). These pros and cons of 
the gigas effects make the induction of the autoploids more suited to crops whose economic part is vegetative. The primary technique for inducing autopolyploids is the utilization of colchicine $\left(\mathrm{C}_{22} \mathrm{H}_{25} \mathrm{O}_{6}\right)$, an alkaloid from Colchicum autumnale [2].

Production of larger leaves and other plant parts can be refined by enlistment of polyploidy. Tetraploids have bigger leaf size, thickness and have potential use in expanding biomass and yield in examination with diploid strains. Characters of interest with low variability in the population might be enhanced through mutation breeding [3].

Flow-cytometry (FCM) would seem to offer points of interest in plant reproducing and may be utilized. Exceptionally fast and simple marker for ploidy manipulation for example, polyploidisation by colchicine [4].

Ploidy level assessed by Flowcytometry (FCM) of nuclei showed that the putative measured fluorescence is connected with the DNA content of the stained nuclei. Ploidy level can be concluded by comparing peak position of G1 nuclei of a plant with known ploidy with that of unknown sample .Tetraploids had twofold the measure of DNA affirming autotetraploidy and an important advantage of FCM over other different techniques the ability to identify mixoploid and greatly increased the efficiency of screening ploidy levels at critical steps in this investigations. Counting of chromosomes is not easy and time-consuming furthermore this method isn't appropriate for discovery of mixoploidy in tissues with low proportion of dividing cells such as leaves.

A few techniques are known for deciding the quantitative substance of glycosides in plant material (e.g. gas chromatography or infrared spectroscopy). However, the least difficult and most dependable technique is high-performance liquid chromatography (HPLC), which has been utilized to determine the composition of $S$. rebaudiana growing in various geographical areas [5].

Materials and methods

Plant material

Saplings of Stevia rebaudiana were collected from genetic stock at the Department of Horticulture, University of Agricultural Sciences, GKVK campus Bangalore-65 and the plants were raised in greenhouse of 
the Department of Plant

Biotechnology, University Of

Agricultural Sciences, GKVK campus, the place is located at $12^{\circ} 58^{\prime}$ latitude North and $77^{\circ} 35^{\prime}$ longitude East of Bangalore-65, Karnataka, India.

Induction of genetic variability by colchicine treatment:

Genetic variability was induced by different dosage of colchicine. The axillary buds of 60 days old plants in the greenhouse were treated with colchicine. The treatments were imposed on February 2012.

Emerging meristem tissues of axillary buds in basal position of shoot of each of the twenty saplings were treated. The treatments employed in the experiment were as follows: $\mathrm{T} 1=0.25 \%$, $\mathrm{T} 2=0.50 \%, \mathrm{~T} 3=1.0 \%, \mathrm{~T} 4=1.5 \%, \mathrm{~T} 5=2.0$ $\%$ and $\mathrm{T} 6=2.5 \%(\mathrm{w} / \mathrm{v})$ aqueous solution of colchicine (Sigma), 'cotton plug method' was adopted and colchicine soaked cotton was placed on the axillary buds. Colchicine treatments were given for three days by placing drops of colchicine solution on cotton wads. Each treatment was replicated twenty times.

After 5 days, untreated buds and branches were removed, to enhance the growth of the treated buds, flowering buds were removed after 60 days of treatment. Among the treated plants only the plants which showed morphological differences were selected for morphological, anatomical, Flowcytometry and Stevioside content determination.

Morphometric studies

The morphometric analyses were documented after 180 days from the treatment which focused on some vegetative parameters such as plants height $(\mathrm{cm})$, length $(\mathrm{cm})$, width $(\mathrm{cm})$ and thickness $(\mu \mathrm{m})$ from third position of apical shoot, stomata density and number of inflorescence per plant.

Flow cytometry analysis:

The ploidy level of the control and treated plants was determined by Flow-cytometry. The Flow-cytometry (FCM) machine aligns the nuclei by hydrodynamic focusing uses a light source to illuminate the stained nuclei, and detects the fluorescence emitted. The amount of fluorescence in every nucleus is connected with its DNA content.

Nuclear DNA content was determined using Flowcytometry of isolated nuclei stained with propidium iodide (PI) $25 \mu \mathrm{g}$ per $\mathrm{ml}$ and $2 \mathrm{mg} / \mathrm{ml}$ ribonuclease as indicated [7]. Leaf tissue 
of each analysed accession was chopped in LB 01 buffer, and nuclei were passed through a $30 \mathrm{~lm}$ nylon mesh.

The suspension was investigated by utilizing a flowcytometry (BD FACS Calibure, USA, National Centre for Biological Science, Bangalore) to determine mean relative DNA fluorescence (Mean Relative Fluorescence, MRF). Ploidy and genome estimate were determined by comparing the MRF of each sample with the $2 \mathrm{C}$ peak of diploids and a standard of known genome size. Pisum sativum L., with a genome size of $9.1 \mathrm{pg}$, was used as an internal standard to calculate nuclear DNA content [(2C DNA content of sample in $\mathrm{pg}=9.1 \mathrm{pg} \times(\mathrm{MRF}$ sample/ MRF standard)]. For analysis of leaf tissue the coefficient of variation percentage $(\mathrm{CV} \%)$ was $\leq 2.00$ and at least 2400 nuclei were analysed.

Extraction and purification of Stevioside from stevia plant:

The dried ground leaves two grams of Stevia were extracted by HPLC grade water $250 \mathrm{ml}$ and filtered by whatman filter paper No. 4 for five times, the filtrates collected and then concentrated by using rotary evaporator at $98^{\circ} \mathrm{C}$ to the maximum concentration value and made up the volume up to $100 \mathrm{ml}$ with HPLC grade water.
Estimation of Stevioside:

High-Performance liquid Chromatography (HPLC) analysis was done in the department of Horticulture (Shimadzu LC solution, Japan), to estimate the Stevioside in dried leaves of Stevia rebaudiana [7] . I. Chromatography Conditions: The mobile phase was HPLC grade water: HPLC grade acetonitrile ratio (25:75), flow rate: $1 \mathrm{ml} / \mathrm{min}$, detection wavelength: 210nm, column: $\mathrm{NH}_{2}, \mathrm{C} 18$ column (250 $\mathrm{mm} \times 4.6 \mathrm{~mm}$ ) and injection volume: 20

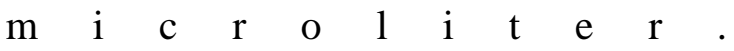

II. Standard for Stevioside:

Reference-standard:

Stevioside of pure form (99\%) obtained from sigma (USA) was the reference compound stock solution: The reference compound $10 \mathrm{mg}$ in quantity was dissolved in $1 \mathrm{ml}$ of HPLC grade water to make stock solution of $10000 \mathrm{ppm}$ or a concentration of $10 \mathrm{mg} / \mathrm{ml}$. Injection of standard: The above concentration of Stevioside was clarified using sample clarification kit and was injected into injection port with 20 microliter loop being attached to the HPLC unit. The run time was fixed at 20 minute and the Calibration was a particular peak with retention time of ten minute was identified as the standard concentration peak of Stevioside. 
Procedure for estimation of Stevioside in leaf samples:

Dried leaves were made into fine powder by pestle and mortar. Two grams of leaf powder was taken for extraction from each treatment then added $100 \mathrm{ml}$ of HPLC grade water and mixing it with magnetic stirrer for two minute then filtered with whatman paper and washing for 5 times. The filtrates were taken in around bottom flask and the flask was fitted to a rotatory evaporator, the evaporation procedure was continued until a minimum amount of the extract remained in the flask. The volume of remaining extract was made up to $100 \mathrm{ml}$ by adding HPLC grade water and the filtrates again filtered by vacuum filtration and kept in room temperature. The mobile phase preparation was acetonitrile (HPLC grade) and HPLC grade water were used for mobile phase preparation, the filtered (clarified) solvents were connected to two different pumps of HPLC and the flow rate adjusted to $1 \mathrm{ml}$. The Injection of sample solution, the leaves extracts of the samples thus prepared after clarification were injected $(20 \mu \mathrm{l})$ port with the help of $25 \mu \mathrm{l}$ syringe. Before injection the syringe was thoroughly rinsed with HPLC grade water and then with the sample .The excess fluid was collected in a bottle. The run time was adjusted for 20 minutes. After injection the syringe was thoroughly rinsed with HPLC grade water and used for further injections.

\section{Calculation :}

Stevioside content (100\%) was calculated by using the equation:

HPLC reading $\times$ concentration of standard $\times$ purity of standard/

Area of standard $\mathrm{x}$ concentration of sample $(\mathrm{mg} / \mathrm{ml})$

Statistical analysis and interpretation of data:

Random Complete Block Design (RCBD) was used in the experiment. The information of morphometric studies was subjected to two way analysis of variance as outlined by [8]. However statistical analysis of the data on Stevioside content was not carried out as a single leaf, extract from several leaves was used for Stevioside estimation through HPLC.

\section{Results and Ddiscussion:}

Induction of genetic variability by colchicine treatments:

Cent percent survival of buds was observed in control after two weeks of the treatment. Among the treated buds survival percentage ranged from 39 percent in T6 
to 75 percent in T1. Mean survival across treatments was 58.13 percent.

In this study the tetraploidy was induced by the treatments $\mathrm{T} 3$ and $\mathrm{T} 4$. This corresponds to 1.5 and $2 \%$ of colchicine respectively. Triploidy was observed in T4, T5 and T6 while Mixaploidy was noticed in $\mathrm{T} 2$.

Identification of polyploidy through morphological, anatomical and

Flowcytometry studies:

Results showed significant difference in morphological and anatomical characters between control and polyploidy plants.

Plant height $(\mathrm{cm})$ for all the colchicine treated plant showed higher plant height compared to control. Plant height varied from $46.4 \mathrm{~cm}$ in $\mathrm{T} 1$ to 90.5 $\mathrm{cm}$ in T6-1, among the treated plants. In the control it was $40.4 \mathrm{~cm}$, the treatment T6-1 (2.50\% colchicine) resulted in $125 \%$ increases in plant height (Table 1), the leaf length $(\mathrm{cm})$ ranged from 4.5 in $\mathrm{T} 1$ to 6.8 $\mathrm{cm}$ in T4-1, among the treated plants, in the control it was $3.8 \mathrm{~cm}$. The treatment T4-1 (1.50\% colchicine) resulted in $79 \%$ increas in leaf length as compered to control the control. Leaf width $(\mathrm{cm})$ ranged from 2.6 in T4-2 Leaf thickness $(\mu \mathrm{m})$ ranged from 124.2 in T6-1 to 176.9 $\mu \mathrm{m}$ in $\mathrm{T} 5$, among the treated plants in the control it was $122.0 \mu \mathrm{m}$. The treatment T5 $(2.00 \%$ colchicine) resulted in $45 \%$ increase in leaf thickness as compared to control. The Stomata density $\left(\mathrm{mm}^{2}\right)$ in the leaves ranged from 12 in $\mathrm{T} 2$ to 27 in T6-2 per unit area, among the treated plants in the control it was $30 \mathrm{~mm}^{2}$ per unit area. The treatment T2 (0.50\% colchicine) resulted in $60 \%$ decreases in stomata density as compared to control the number of inflorescence per plant ranged from 20 in $\mathrm{T} 1$ to 40 in $\mathrm{T} 3-1$ per plant, among the treated plants, in the control it was 15.The treatment T3-1 (1.00\% colchicine) resulted in $62.5 \%$ increases in Number of inflorescences per plant as compared to control. (Table 1).

There was significant difference between the control and the polyploidy plants in the parameters of plant height, leaf length, width and thickness. Polyploids are expected to be taller, having thicker, wider and dark green leaves. The result in the present investigation also supports the above mentioned works, in which tetraploid Plants had the larger and longer leaves

$(6.8 \mathrm{~cm})$, greater leaf width $(3.7 \mathrm{~cm})$ and thickness $(173.60 \mu \mathrm{m})$, and taller plants 
$(90.5 \mathrm{~cm})$. The polyploids were also found to have darker green colour leaves than the control plants (Diploid) due to higher content of chlorophyll in the cells. The stomata number per unit area (12) was lesser in polyploids, while the number of inflorescences per plant (36) was higher.

Breeding of triploid plants of Stevia was done by [9], and 42 triploid plants, grouped into eight cultivars, were obtained. The chromosome number of these plants, obtained by counting the chromosome number of root tip cells and by Flowcytometry analyses, showed that the plants were triploid $(2 n=33)$. In these triploid plants, the leaves, flowers and guard cells were larger than that in the plants classified as diploid. The leaf shape of the triploid plants was categorized as needle-like or wide needle-like.

Triploids were shorter than tetraploids but taller than diploid. Leaf length, leaf width, leaf thickness, number of inflorescences per plant and Stevioside content were higher in colchicine treated plants. Stomata number per unit area was less in tetraploid and triploid compared to diploids plants. These results are agreement with [9].

There was significant difference in stomata number in the similar ploidy level of events. Decreasing stomata number caused by increasing ploidy level has been observed in Salvia miltiorrhiza [10], in S. rebaudiana [11], Spathiphyllum wallisii [12], Miscanthus sinensis and $M$. sacchariflorus [13] reported correlation of stomata size with genome size in $M$. sinensis. In M. sacchariflorus, [1] in Tanacetum parthenium Schulz-Bip., spathiphyllum [15], and in Strawberry [14]. [13] Reported correlation of stomata size with genome size in Miscanthus giganteus, M. sinensis and M. sacchari florus. The stomata size [17] and chloroplast number of guard cell of stomata [18] could be used to distinguish normal and polyploidy plant. In general all the polyploidy plants showed increases in plant height.

The Chromosome number of $S$. rebaudiana $2 \mathrm{n}=22$, previously reported [19],[ 20]. [21] reported that tetraploid plants of strawberry from protoplast culture had larger vegetative parts. Similar characters were found in Salvia miltiorrhiza [10], Arboretum spp. $(4 \mathrm{x}=2 \mathrm{n}=52) \quad$ [22], Petunia [23], Spathiphyllum wallisii[12], Miscanthus sinensis and M. Sacchariflorus [13]. 
Table 1. Plant height, leaf length and width, leaf thickness, stomata number per unit area, inflorescence number per plant, and Stevioside content percentage in colchicine treated plants.

* Significant at 5\% level

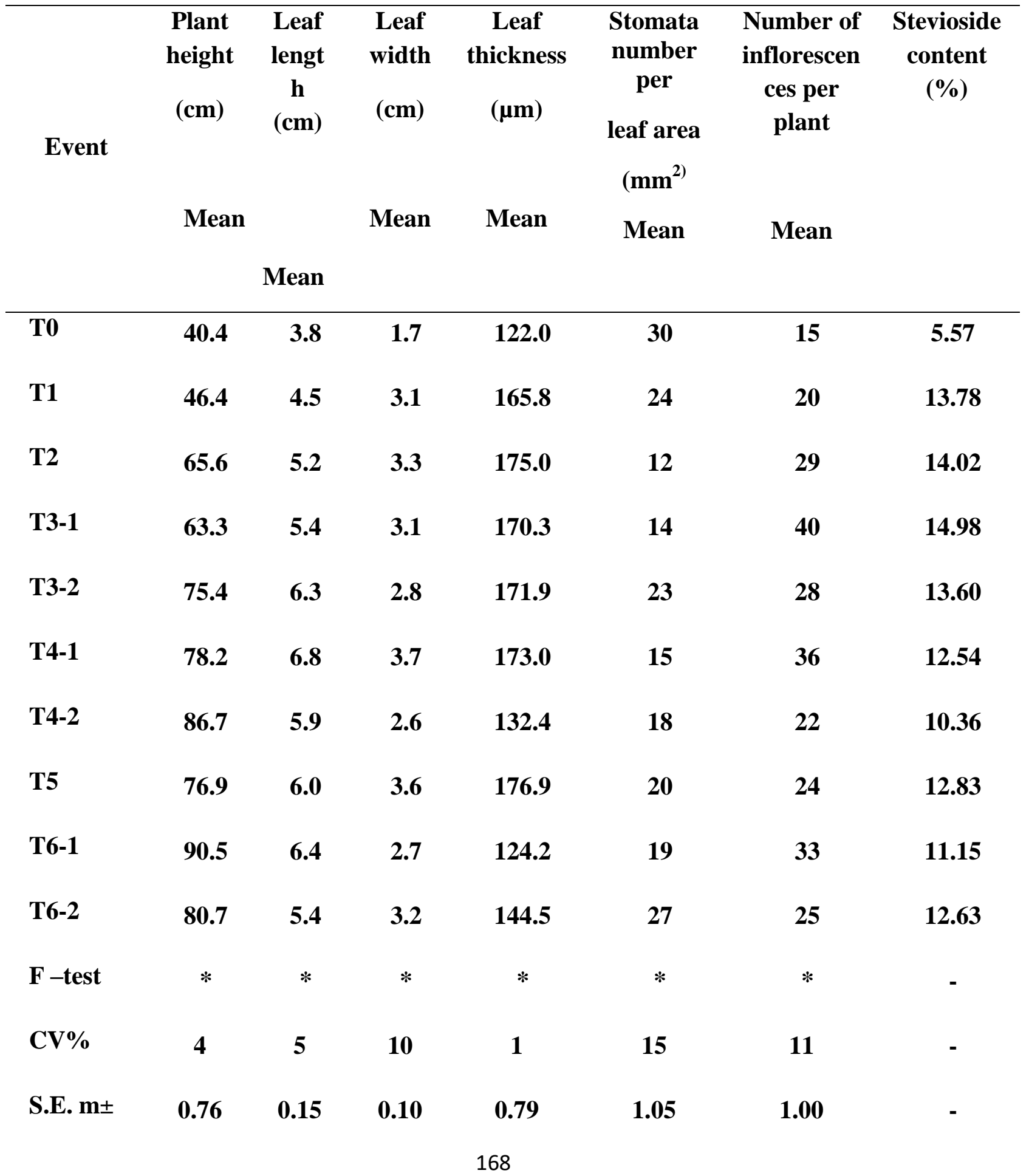




\section{Flowcytometry analysis}

Pisum sativum L., with a genome size of $9.1 \mathrm{pg}$, was used as an internal standard calculate nuclear DNA content. Ploidy level of buds from colchicine treated, as well as control (diploid) plants were determined by Flowcytometry analysis. Histograms from Flow-cytometry analysis reveal peak of the nuclear DNA content corresponding to diploids $2 \mathrm{x}$ (Table 2, Figures: 1), triploids 3x (Table 2, Figure: 2), tetraploid 4x (Table 2, Figures: 3) and mixaploid (Table 2, Figure 4) respectively. Flow-cytometry greatly facilitated the screening for ploidy levels after treatment with spindle inhibitor, as reported [6, 24]. Flowcytometry histograms revealed

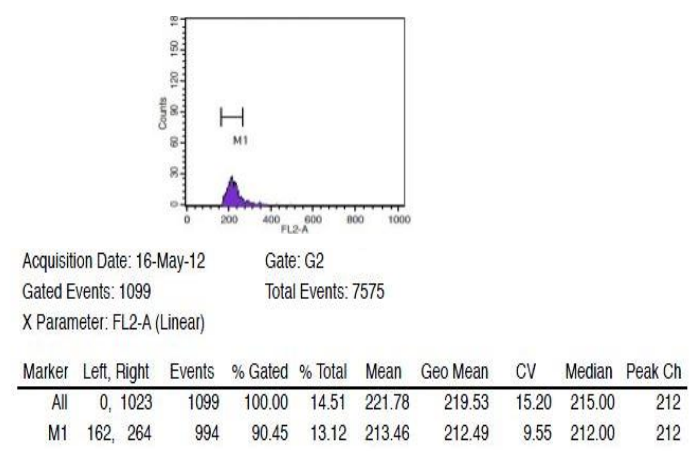

Figure 1. Flow cytometry histogram statistics of Stevia rebaudiana for control (Diploid).

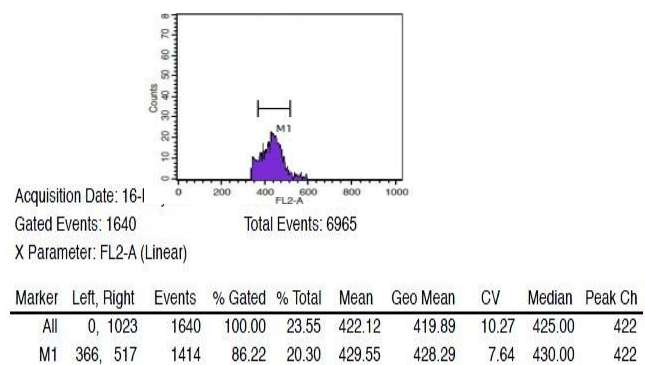

Figure 3. Flowcytometry histogram statistics of Stevia rebaudiana for Tetraploid. diploid, tetraploid and higher polyploidy level. Tetraploid were recovered when the shoots were treated with $1.5 \%$ and $2 \%$ colchicine. These results confirm the ploidy level of Stevia rebaudiana, as diploid, triploid, tetraploid and mixaploid. Ploids of buds from colchicine treated, as well as control (diploid) plants were determined with Flowcytometry analysis (Table 2). Histograms from Flowcytometry analysis reveal the nuclear DNA content corresponding to diploids, triploids, tetraploid and mixaploid respectively.

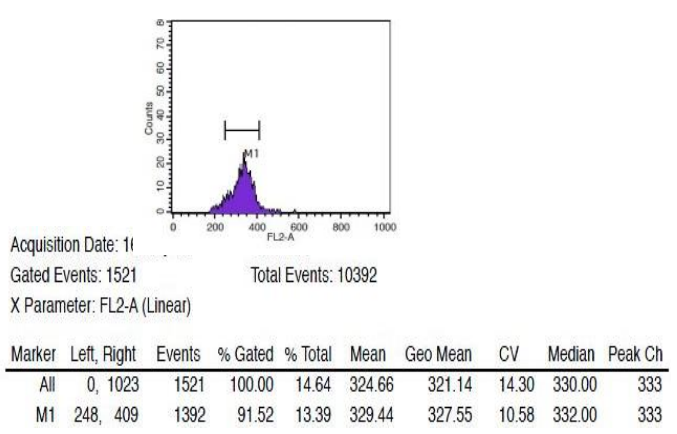

Figure 2. Flow cytometry histogram statistics of Stevia rebaudiana for Triploid.

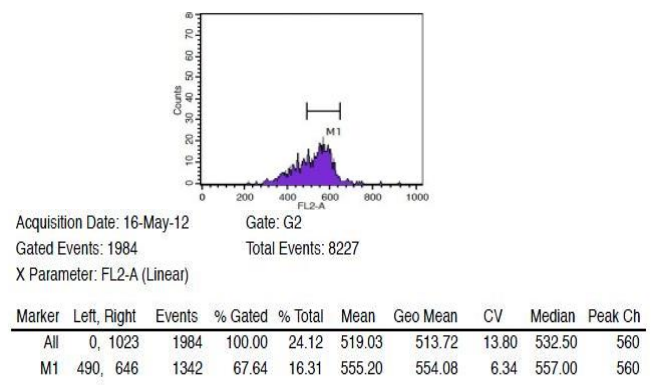

Figure 4. Flow cytometry histogram statistics of Stevia rebaudiana for $16 i$ aploid. 
Table 2

DNA concentration in the leaf samples

\begin{tabular}{|l|c|c|}
\hline Events & $\begin{array}{c}\text { DNA } \\
\text { concentration(ng/ } \boldsymbol{\mu l})\end{array}$ & $\begin{array}{c}260 / 280 \\
\text { nm } \\
\text { Ratio }\end{array}$ \\
\hline T0 & 1433.1 & 2.11 \\
\hline T1 & 315.3 & 2.16 \\
\hline T2 & 352.1 & 2.22 \\
\hline T3-1 & 419.9 & 2.02 \\
\hline T3-2 & 328.6 & 2.18 \\
\hline T4-1 & 268.2 & 2.18 \\
\hline T4-2 & 280.4 & 2.05 \\
\hline T5 & 951.6 & 2.09 \\
\hline T6-1 & 1126.0 & 2.13 \\
\hline T6-2 & 105.6 & 1.69 \\
\hline
\end{tabular}

and relative ratio of DNA to proteins.

\section{Stevioside content:}

The Stevioside content in the leaves of Stevia plants ranged from $5.57 \%$ in $\mathrm{T} 0$ to $14.98 \%$ in T3-1 (Tetraploid). Among the treated plants lowest 10.36 in T4-1. In general the colchicine treated plants showed higher Stevioside content than the control (Table 1, Figures: 5, 6, 7, and 8).
In the present study, among the various events, of $S$. rebaudiana highest Stevioside content was recorded in the T31, Least Stevioside content was recorded in the T4-2, the diploid plants which obtained after colchicine treatment also recorded high Stevioside content compared to control which is diploid also (Table 1).The leaves of Stevia rebaudiana (Bertoni) accumulate at least eight Steviol glycosides (SGs), the concentrations of which vary quite widely depending on the genotype [25]. Even though recorded on par results for various morphological T3-1 yielded maximum Stevioside in their leaves Thus, it revealed that Stevioside content in leaves of Tetraploid plants are dependent on leaves characters. The thickness of leaf was associated with greenness of leaf.

The glycoside quality of Stevia is improved by using the polyploidy. Stevioside content is influenced by both leaf surface and number of roots; however, the leaf surface has more influence on Stevioside content than the number of roots [26]. 


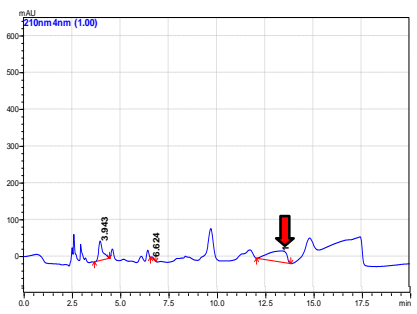

Figure 5. HPLC profile of Stevia leaf for control (diploid)

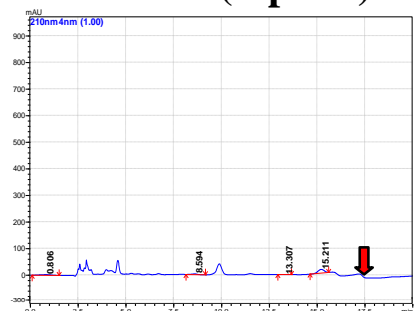

Figure 6. HPLC profile of Stevia leaf for Triploid

\section{Acknowledgment}

I am grateful to the Department of Biotechnology, Department of Horticulture, GKVK, UAS, and NCBS, Bangalore for providing facilities this research.

\section{Referances}

1. Abdullateef, R. A. and Osman, M., 2012. Studies on Effects of Pruning on Vegetative Traits in Stevia rebaudiana Bertoni (Compositae). Int. J. Biol., 4(1).

2. Acquaah, G., 2007. principles of plant genetics and breeding, T.J., International Ltd, UK.

3. Yadav, A. K., Singh, S., Dhyani, D. and Ahuja P. S., 2011. Review On The improvement of Stevia [Stevia

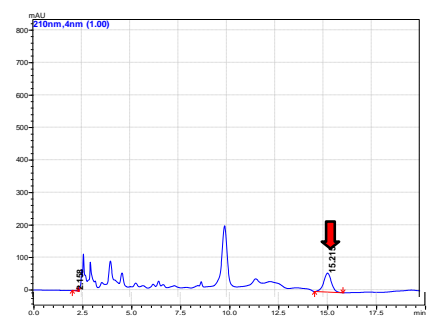

Figure 7. HPLC profile of Stevia leaf for Tetraploid

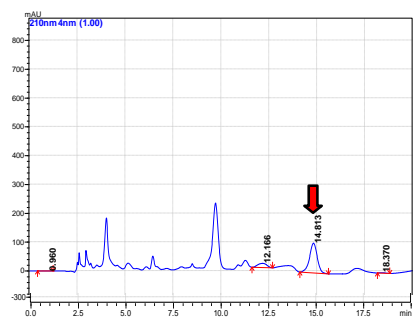

Figure 8. HPLC profile of Stevia leaf for Mixaploid rebaudiana (Bertoni)], Can. J. Plant Sci., 91: (1):1-27.

4. Costich, D. E., Ortiz, R., Meagher, T. R., Bruederle, L. P., and Vorsa, N., 1993. Determination of ploidy level and nuclear DNA content in blueberry by Flowcytometry. Theor. Appl. Genet., 86: 1001-1006

5. Kovylyaeva, G., Bakaleinik, G., Strobykina, I., Gubskaya, V., Sharipova, R. and Alcfonsov, V., 2007. Glycosides from Stevia rebaudiana.

6. Dolezel, J., Binarova, P. and Lucretti, S., 1989. Analysis of nuclear DNA content in plant cells by Flowcytometry. Biol. Planarum., 31:113120. 
7. Woelwer-Rieck, U., Wawrzun, C. and Wu-St, M., 2010. Improved Hplc Method for the evaluation of the major Steviol glycosides in leaves of Stevia rebaudiana. Eur. Food Res. Technol., 231: 581-588.

8. Sundararaj,N., Nagaraju, S., Venkataramu, M.N. and Jaganath, M.K., 1972. Design and analysis of field experiments. University of Agricultural Sciences, Bangalore, Pp. 409.

9. Shuichi, H., Yomo, T.and Satoshi, F., 2001. Breeding of Triploid Plants of Stevia (Stevia rebaudiana Bertoni) with High Rebaudioside A Content. Jpn. J. Trop. Agr., 45: 281-289.

10. Gao, S. L., Zhu, D. N., Cai, Z. H. and $\mathrm{Xu}$, D. R., 1996. Autotetraploid plants from colchicine-treated bud culture of Salvia miltiorrhiza Bge. Plant Cell Tiss. Org. Cult., 47: 7377.

11. Oliveira, V. M., Eliana, R., ForniMartins, Pedro $M$. and Marcos, N A., 2004. Chromosomal and morphological studies ofdiploid and polyploid cytotypes of Stevia rebaudiana (Bertoni) Bertoni (Eupatorieae, Asteraceae).Genet. Mol. Biol., 27 (2):215-222.

12. Vanstechelman, I., Vansteenkiste, H., Eeckhaut, T., Huylenbroeck, J. V. and Labeke, M. V. 2009. Morphological and anatomical characterisation of chemically induced polyploids in Spathiphyllum wallisii. International Society for Horticultural Science(ISHS), Acta.
Horticulturae: XXIII International Eucarpia Symposium, Section Ornamentals: Colourful Breeding and Genetics, 836.

13. Rayburn, A. L., Crawford, J., Rayburn, C. M. and Juvik, J. A., 2009. Genome size of three Miscanthus Species. Plant Mol. Biol. Rep., 27: 184- 188.

14. Murti, R. H., Kim H. Y. and Yeoung, Y. R., 2012. Morphological and anatomical characters of ploidy mutants of strawberry. Int. J. Agric. Biol., 14(2): 204-210.

15.Laere, K. V., Franc, S. C., Vansteenkiste, H., Huylenbroeck, J.V., Steppe, K. and Labeke, M. V., 2010. Influence of ploidy level on morphology, growth and drought susceptibility in Spathiphyllum wallisii Acta. Physiol. Plant, 33: 1149-1156.

16.Majdi, M., Ghasem, K., Malboobi M., A., Omidbaigi, R. and Mirzaghaderi, G., 2010. Induction of tetraploidy to feverfew (Tanacetum parthenium Schulz-Bip.): morphological, physiological, cytological, and phytochemical Chem. Nat. Compd., 43: 81-85.changes. Hort. Sci., 45(1):16 -21.

17. Omidbaigi, R., Mirzaee, M., Hassani, M. E., and Moghadam, M. S., 2010. Induction and identification of polyploidy in basil (Ocimum basilicumL.) medicinal plant by colchicine treatment. Int. J. Plant Production, 4: 87-98.

18. Winarto, B., Mattjik, N. A., Da Silva, J. A. T., Purwito, A. and Marwoto, B., 2010 . Ploidy screening of anthurium (Anthurium andreanum 
Linden ex andre) regenerants derived from anther culture. Sci. Hort., 127:86-90.

19. Monteiro, R., 1980. Taxonomia $e$ biologia da reproducao de SteviarebaudianaBert. Master's Thesis, UniversidadeEstadual de Campinas, Campinas.

20. Monteiro, R., 1982. Estudos cromossomicos em Stevia rebaudiana-Serie Multiaristataeno Brasil, Rev. Bras.Bot., 5:5-15.

21. Nyman, M. and Wallin, A., 1993. Somaclonal variation in protoplastderived strawberry plants. II International Strawberry Symposium. Acta. Horticulturae, Maryland, USA, vol. 348.

22. Rauf, S., Khan, I. A. and Khan, F. A., 2006. Colchicine-induced tetraploidy and changes in allele frequencies in colchicine-treated populations of diploids assessed with RAPD markers in Gossypium arboretum L. Turk J. Biol., 30: 93-100.

23. Guo-Gui, N., Xue-Ping, S., Hui-Rong, H., Yan, Y. and Man-Zhu, B., 2009. Development of a range of Polyploid lines in petunia hybrida and the relationship of ploidy with the single/double flower trait. Hort. Sci., 44: 250-255.

24. Ochatt, S. J., Patat-Ochatt, E. M. and Moessner, A., 2011. Ploidy level determination within the context of in vitro breeding. Plant Cell Tiss. Org. Cult., 104: 329-341.

25. Brandle J. E. and Telmer P. G., 2007. Steviol glycoside biosynthesis, Phytochem. 68:1855-1863.
26. Truong, T. T., Valicek, P., Nepovim, A. and Vamel. T., 1999. Correlation between Stevioside content in leaves, their surface and the number of roots in the plant. Sci. Agric. Bohemica. 